\title{
Proposed Customer-based Brand Equity (CBBE) Strategy for Railway Courier Service - Case Study: Rail Express of PT Kereta Api Indonesia
}

\author{
Fahmi Aulia Rahman and Nita Garnida
}

\section{ABSTRACT}

PT Kereta Api Indonesia (KAI) is a railway transportation service provider in Indonesia. In 2019, KAI launched railway courier service to support logistic sector, called Rail Express. Despite the advantages of railway courier service in providing low-cost fee and minimum risk of time delay and accident, low market penetration indicates brand awareness in the market is still very low. The main objective of this study is to develop customer-based brand equity strategy for railway courier service, by using Rail Express as the case to carry out the research. This study used a series of qualitative method research to fully comprehend the business situation and propose the solution to the business problem. First, in-depth interviews were conducted to the management and staff of KAI to assess external and internal environments of railway courier service. Second, focus group discussions were conducted to gain consumers' insight related to brand awareness and brand image of Rail Express. The discussion was attended by 16 participants that represent Rail Express target market of e-commerce buyer and seller. Third, this study used TOWS matrix to generate business solution alternatives based on previous analysis findings. As the result, this study formulated three main strategies to build customer-based brand equity: first, integrated marketing communication to establish brand awareness by increasing brand recall and brand recognition; second, brand repositioning to establish brand image by developing brand associations related to positive image and technology; and third, improvement on existing marketing mix, i.e., product, distribution channel, and price strategies.

Keywords: Brand awareness, Brand image, Customer-based brand equity, Railway courier services.

Published Online: January 7, 2021

ISSN: 2507-1076

DOI: $10.24018 /$ ejbmr.2021.6.1.670

Fahmi Aulia Rahman*

(e-mail: fahmi.aulia@sbm-itb.ac.id)

Nita Garnida

*Corresponding Author

\section{INTRODUCTION}

Indonesia is the world's largest island country, with more than seventeen thousand islands, with the total area of $1,904,569$ square kilometers. It is understandable that Indonesia connectivity must be developed to cover the whole area. Then, mode of transportation becomes the paramount importance to ensure the smooth traffic of goods, either by road, sea, or air transportation all around the country's region. Currently, Indonesia has the biggest logistic cost in Asia, approximately $24 \%$ of Gross domestic product or USD 266.48 million [14]. One of good and efficient transportation is railway transport. Railway transport can provide not only low-cost fees, but also provide minimum risk of time delay and accident. PT Kereta Api Indonesia (KAI) is one of the state-owned enterprises that provides public railway transport in Indonesia. In 2019, KAI launched Rail Express to provide retail courier service using railway transport, especially to cover Java Island.

Previously, KAI focuses on the rail forwarder companies as the main customer of Rail Express, in addition to ecommerce companies and individual users. Triggered by the growth of e-commerce business in Indonesia, KAI is starting to shift its focus to e-commerce users, i.e., the sellers and the buyers. However, Rail Express is still experiencing low market growth and penetration, which indicates brand awareness of Rail Express in e-commerce market is still very low. Previous research confirmed brands that consumers know are more likely to be included in the consumers' consideration set to purchase [4], [10]. In particular, the awareness set plays an important role in the information search stage of consumer decision making process [9]. One of the concepts that is able to elevate brand awareness and brand image is Customer-based Brand Equity (CBBE) [6]. Accordingly, the objective of this study is to develop CBBE strategy for railway courier service, as an effort to establish brand awareness and brand image of Rail Express, the case of this study.

\section{LITERATURE REVIEW}

\section{A. Customer-based Brand Equity}

The basic thinking of customer-based brand equity concept is brand power lies in what customers already learned, felt, 
seen, and heard about the brand based on their experiences over time [6]. Then, CBBE is defined as the differential effect of brand knowledge has on consumer response from the marketing of that brand [6]. Brand knowledge consists of two dimensions, i.e., brand awareness and brand image. Brand awareness is the consumer's ability to identify a specific brand in several situations. Brand awareness is divided into two dimensions, which are brand recall and brand recognition. Brand recall is the ability of consumer to acquire the brand from individual memory when the product category is mentioned or when product function is used as a stimulus. Brand recognition is the ability of the consumer to confirm brand exposure when a brand stimulus is given. Brand image is consumers' perceptions towards the specific brand based on brand associations in consumer memory.

\section{B. External Environment}

A firm's external environment consists of all the factors that can affect its potential to gain and sustain a competitive advantage [12]. By analyzing the factors in the external environment, managers can mitigate threats and leverage opportunities. One common approach to understanding how external factors impinge upon a firm is to consider the source or proximity of these factors [12].

\section{Internal Environment}

An internal environment of an organization can be analyzed through its resources, competencies, and competitive advantages. Performing an internal analysis allows the company to identify the strengths and weaknesses of the internal condition. This knowledge then aids the strategic decision making of management while they carry out the strategy formulation and execution process.

\section{MethodolOGY}

This study uses the qualitative method with the consideration only limited people fully comprehend Rail Express and the nature of this research that needs in-depth information from internal and external environments. Qualitative research is a method to gain insight into and understanding of the problem condition [11]. To collect the primary data, the authors conducted in-depth interview to stakeholders of KAI for obtaining information related to external and internal environments of Rail Express; and focus group discussion (FGD) to 16 e-commerce users, i.e., the sellers and the buyers that represent Rail Express target market, for obtaining consumer insight related to brand awareness and brand image of Rail Express. The authors also collected secondary data, such as company internal data, competitor data, and published scientific paper to support the primary data.

\section{FINDINGS AND ARGUMENT}

\section{A. External Environment Analysis}

Based on interview with the management and staff of KAI, there are three external factors that generates opportunities for Rail Express. First, government regulation on standard delivery service encourages Rail Express to increase its service performance. Second, e-commerce growth in terms of business revenue, which increases up to $57.29 \%$ in 2019; as well as e-commerce user growth, which is predicted to increase up to 212.2 million in 2023 [15]. Third, technological advancement particularly in smart logistics that could improve courier service capabilities and features.

The external environment analysis also identifies threats from two external factors, i.e., service substitution alternatives such as air courier service, sea courier service, and road courier service; and competition from other brands in courier service category, such as JNE, which has wide range of services; J\&T Express, which has extensive marketing communication program; and Wahana Express, which offers the most affordable price.

\section{B. Internal Environment Analysis}

Based on interview with the management and staff of KAI, there are three internal factors that become the strengths of Rail Express. First, Rail Express gets the advantage from its corporate brand, KAI, which has strong brand awareness and brand image as the railway transport in Indonesia. Second, Rail Express also gets the advantages of the nature of rail transport, which is very safe, thus minimize the risk of accident in delivery service; and has wide space of compartment as such it is able to deliver all variance of goods with relatively unlimited volume. Third, Rail Express has innovation in special caring of goods, i.e., specific packaging, high standards caring, and additional caring security.

While for its weaknesses, this study identified four internal factors. First, KAI does not perform sufficient marketing communication to introduce Rail Express to its target market Second, limitation in technology application as such Rail Express is struggling to increase its performance. Third, limitation in distribution channel and product features. Currently, service area coverage of Rail Express is limited to Java island. The delivery of goods is also limited at stationto-station service as such consumers should put extra effort to go to the rail station and pick up the goods. Fourth, limitation in product supporting features, such as insurance, digital payment, and special terms of payment.

\section{Focus Group Discussion}

Respondents profile represents two target market of Rail Express, which are e-commerce users, i.e., the buyers and the sellers. Majority of respondents are young adult at the age 2029 years old $(93.8 \%)$ and live at Java Island. The occupation of respondents are entrepreneur $(31.3 \%)$, private employee $(31.3 \%)$, and college student $(31.3 \%)$ with average income of IDR 2.5 million until 5 million per month (37.5\%).

First, this study assessed two factors of brand awareness, i.e., brand recall and brand recognition. The FGD analysis result revealed that among 15 courier service players in Indonesia, Rail Express has the lowest brand recall and brand recognition. Majority of respondents could not recall Rail Express when courier service category was mentioned. They also admitted that they did not know and never used Rail Express services. Learning from Herona, the top-of-mind brand in railway courier services, the respondents said that this brand was chosen with the reasons brand familiarity, positive experience, and wide destination network.

Second, this study assessed brand image of Rail Express. Adapted the work of Bluemelhuber et al. [3], this study identified the brand image of Rail Express using three stages 
of brand concept mapping process, i.e., first, elicitation stage to gain respondent associations toward Rail Express; second, the mapping stage to find out how salient associations are connected one to another and to the Rail Express as well as the strength of the connection between associations and to the brand; and third, aggregation and codification stage to generate a consensus brand map, which were combined from individual brand maps in the previous stage.

As the result, this study generates two aggregation maps of e-commerce buyer and e-commerce seller segments, which are presented in Fig. 1 and Fig. 2. Accordingly, brand image revealed consumer negative associations that directly relate to Rail Express brand, such as 'not safe enough', 'no insurance', 'no tracking system', 'not practical', 'limited network', 'area coverage: Java Island', and 'not door to door services'; as well as positive associations such as 'cheap', 'fast', 'suitable for big items', and 'big quantity'. These findings give insight for Rail Express to adjust its current positioning, i.e., affordable, fast, and safe by adding positive associations and overcoming negative associations, which in turn will be able strengthen the brand image of Rail Express.

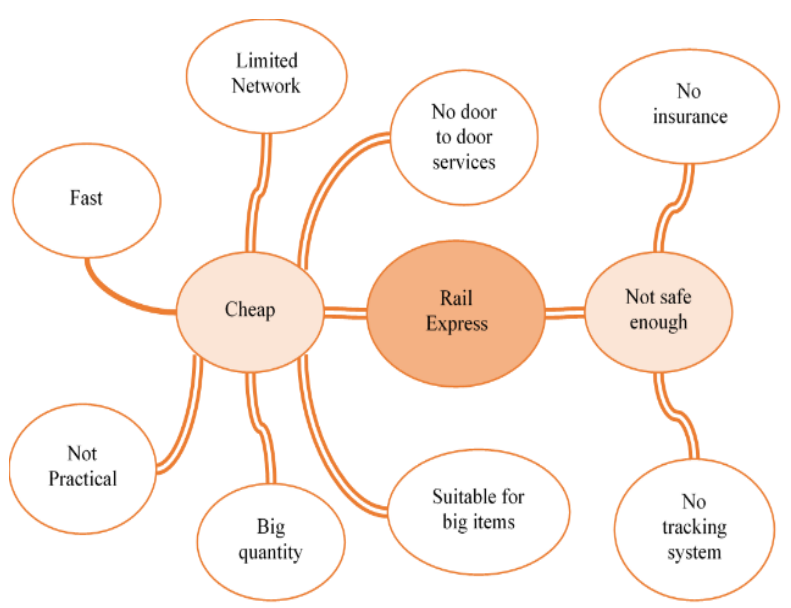

Fig. 1. E-commerce buyer aggregation map.

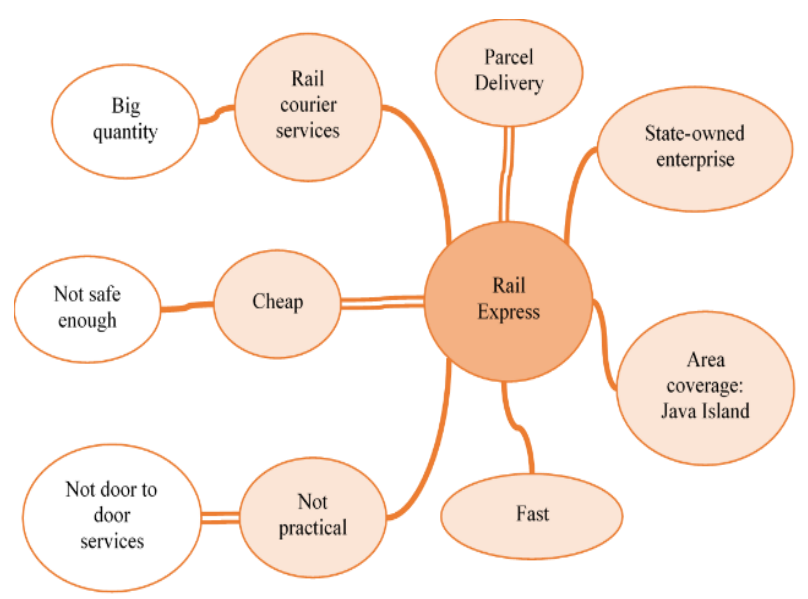

Fig. 2. E-commerce seller aggregation map.

\section{TOWS Matrix}

The TOWS Matrix illustrates how the external opportunities and threats facing a particular company can be matched with that company's internal strengths and weaknesses to result in four sets of possible strategic alternatives, i.e., SO strategy uses the strengths to take advantage of opportunities; ST strategy considers the strengths as a way to avoid threats; WO strategy attempts to take advantage of opportunities by overcoming weaknesses; and WT strategy as defensive and primarily act to minimize weaknesses and avoid threats [12].

Accordingly, the TOWS Matrix analysis using the result of external and internal analysis as well as findings on consumer insight of Rail Express brand awareness and brand image generates 13 business alternative solutions that may overcome the business problem of Rail Express. The result is summarized in Table I.

\section{E. Proposed CBBE Strategy}

Business strategy formulation was conducted to solve business problem of Rail Express which are low brand awareness and several negative brand image; and to meet the research objective. In order to focus at company's problem, this study uses customer-based brand equity (CBBE) approach. The CBBE concept approaches brand equity from the perspective of the consumer whether the consumer is an individual or an organization or an existing or prospective customer. Understanding the needs and wants of consumers and organizations and devising products and programs to satisfy them are at the heart of successful marketing [6]. Customer-based brand equity occurs when the consumer has a high level of awareness and familiarity with the brand and holds some strong, favorable, and unique brand associations in memory [6].

A brand has positive customer-based brand equity when consumers react more favorably to a product and the way it is marketed when the brand is identified than when it is not. In particular, the proposed CBBE strategy is developed based on thirteen TOWS matrix alternatives solution and consists of integrated marketing communication, brand repositioning, and marketing mix of product, distribution channel, and price strategies.

Marketing communications are the means by which firms attempt to inform, persuade, and remind consumers directly or indirectly about the products and brands they sell [6]. Brands attain recognition through marketing communication and advertising, as these are their core promotional mechanisms in the consumer market [13].

The Rail Express marketing communication strategy is divided into two different objectives. First, to develop brand recall, the author proposes classical conditioning advertising through slogan and jingles. Second, to develop brand recognition, the author proposes sales promotion, mobile marketing, online marketing, event and experiences, and public relation. All of the mentioned marketing programs should help customers to recognize Rail Express when the brand attributes are appeared without the brand name mentioned.

Brand repositioning is the act of redesigning a company's offering and image to occupy a distinctive place in the minds of the target market [9]. The Rail Express brand repositioning strategy consists of image and technology repositioning. Image repositioning is an effort to change the negative image of Rail Express in the mind of its target market, i.e., ecommerce buyer and seller. Accordingly, this study proposes new brand associations 'fast', 'safe', and 'easy' courier services for image repositioning. Technology-oriented repositioning creates value added using technological 
approach and still aimed existing target market. Accordingly, this study proposes new brand associations 'Online booking services', 'Online tracking system', and 'Online payment' that enabling consumers to access in one application. To communicate the new brand associations, Rail Express should use them as product taglines in all of product advertisement, as illustrated in the Fig. 3.

\begin{tabular}{|c|c|c|}
\hline Rail Express TOWS Matrix & Strengths & Weaknesses \\
\hline & $\begin{array}{l}\text { (S1) Strong KAI corporate brand awareness } \\
\text { (S2) Minimum risk in delivery services by train } \\
\text { (S3) Able to deliver all variance of goods with relatively } \\
\text { unlimited volume } \\
\text { (S4) Innovation in special caring goods delivery }\end{array}$ & $\begin{array}{l}\text { (W1) Limited area of coverage (Java island } \\
\text { only) } \\
\text { (W2) Limited delivery service (station to } \\
\text { station only) } \\
\text { (W3) Currently does not apply smart } \\
\text { logistics system } \\
\text { (W4) Courier services insurance is not } \\
\text { available } \\
\text { (W5) Only accept cash payment } \\
\text { (W6) No special terms of payment provided }\end{array}$ \\
\hline Opportunities & SO Strategies & WO Strategies \\
\hline $\begin{array}{l}\text { (O1) Government support in freight service } \\
\text { regulation and permit } \\
\text { (O2) E-commerce user growth is high, } \\
\text { predicted to achieve } 212.2 \text { million in } 2023 \\
\text { (O3) Smart logistics technology } \\
\text { development } \\
\text { (O4) Individual consumer positive } \\
\text { associations of Rail Express: 'cheap', 'fast', } \\
\text { 'suitable for big items', and 'big quantity' } \\
\text { (O5) E-commerce seller positive } \\
\text { associations of Rail Express: 'cheap', 'state- } \\
\text { owned enterprise', 'parcel delivery', 'fast', } \\
\text { 'rail courier services', and 'big quantity' }\end{array}$ & $\begin{array}{l}\text { (SO1) Carrying the strong KAI corporate awareness, Rail } \\
\text { Express is branded as the official KAI railway courier } \\
\text { services to attract e-commerce user (S1, O1, O2, O5) } \\
\text { (SO2) Add special caring to reduce delivery risk to attract } \\
\text { e-commerce user (S2, S11, O2, O5) } \\
\text { (SO3) Repositioning Rail Express to fast, safe, and easy } \\
\text { courier service, which is relevant with e-commerce user } \\
\text { (S2, O2, O4, O5) } \\
\text { (SO4) Add railway courier service features including } \\
\text { express delivery, unlimited volume, wide variance package } \\
\text { to attract e-commerce user (S3, O2) }\end{array}$ & $\begin{array}{l}\text { (WO1) Apply smart logistics including } \\
\text { digital administration, digital tracking, and } \\
\text { digital payment (W3, W5, O3) } \\
\text { (WO2) Apply special terms of payment to } \\
\text { increase product attractiveness to e- } \\
\text { commerce user growth (W6, O2) }\end{array}$ \\
\hline Threats & $\begin{array}{l}\text { ST Strategies } \\
\end{array}$ & $\begin{array}{c}\text { WT Strategies } \\
\end{array}$ \\
\hline $\begin{array}{l}\text { (T1) Substitution alternatives from air } \\
\text { freight, sea freight, and road freight services } \\
\text { (T2) Competitors have more product variety } \\
\text { and consumer services }\end{array}$ & $\begin{array}{l}\text { (ST1) Develop product variety and consumer services (S3, } \\
\text { S4, T1, T2) } \\
\text { (ST2) Apply high intensity of product communication and } \\
\text { promotion (S1, T1, T3) }\end{array}$ & $\begin{array}{l}\text { (WT1) Add more distribution agents and } \\
\text { expand network destination (W1, T1, T4) } \\
\text { (WT2) Collaborate with other courier } \\
\text { services to expand the service in all } \\
\text { Indonesia's area (W1, T1, T4) }\end{array}$ \\
\hline $\begin{array}{l}\text { (T3) Competitors conduct intense promotion } \\
\text { and campaign } \\
\text { (T4) Competitors have wide distribution } \\
\text { agent, channel, and network destination }\end{array}$ & (ST3) Apply digital marketing program (S1, T1, T3) & $\begin{array}{l}\text { (WT3) Provide delivery insurance (W4, T1, } \\
\text { T2) } \\
\text { (WT4) Provide door to door services (W2, } \\
\text { T1, T2) }\end{array}$ \\
\hline
\end{tabular}
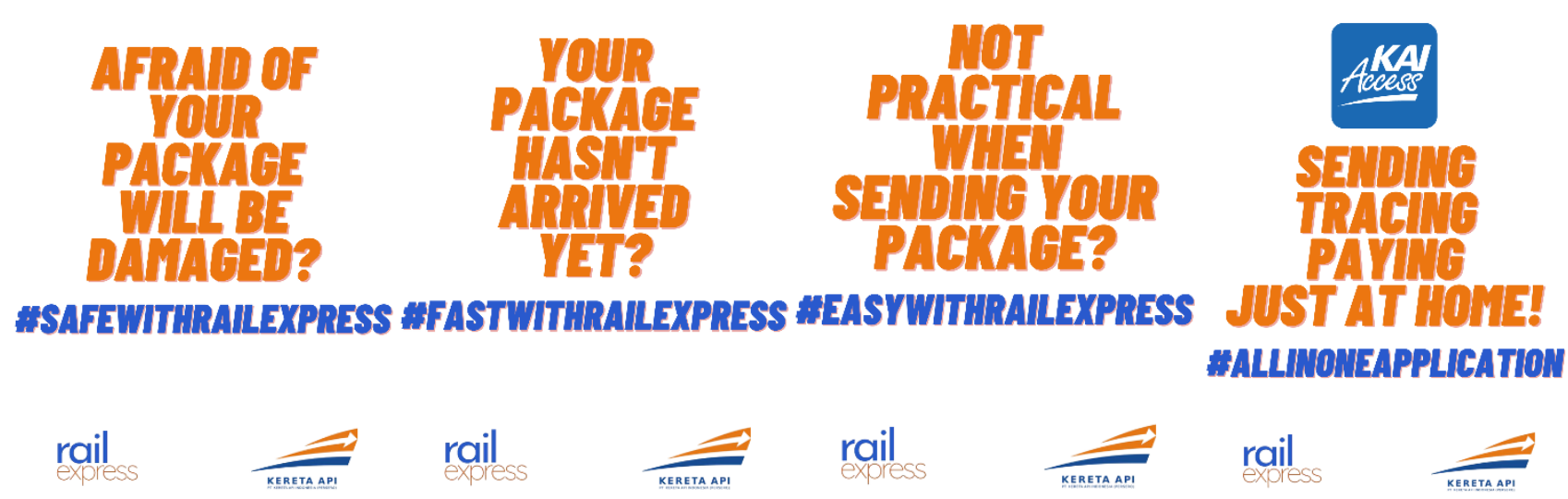

Fig. 3. Rail Express Poster Advertisement Samples.

Product strategy uses both tangible and intangible benefits of the product that consumers desire and the marketing program can deliver [6]. The product strategy is divided into seven section which are product variety, quality, features, brand name, sizes, services, and warranty. The objective is to provide new features that could solve limitation in technology application. While the objective of adding new product variety, quality, features, sizes, services, and warranty is to solve limited product variety and consumer services.
Distribution channel strategy includes designing and managing direct and indirect channels to build brand awareness and improve the brand image [6]. The new distribution channel strategy is divided into five section which are channels, coverage, locations, inventory, and transportation. The objective is to expand the distribution channel by adding new channels, and increase the coverage, inventory, and transportation access to solve limitation in distribution channel. 
Price strategy set prices and adjusting them, if at all, over the short and long run [6]. The new price strategy is divided into four section which are list price, discounts, payment method, and payment period. The objective is to provide new payment period (special terms of payment) as the problem solving to limited product features related to pricing.

\section{CONCLUSIONS AND RECOMMENDATION}

This study has investigated the causes of low brand awareness of railway courier service by analyzing the business situation of external and internal environment of the company; and by gaining consumer insights related to brand awareness and brand image factors. As the result, this study proposes CBBE strategy, which consists of the following:

- Integrated marketing communication to establish brand awareness by increasing brand recall and brand recognition.

- Brand repositioning to strengthen brand image with positive associations and to overcome the negative associations.

- Improving marketing mix by developing product, distribution channel, and price strategies

Even though this study uses a single company, Rail Express as the case study, the proposed CBBE strategy could be useful as an insight for other companies to increase brand awareness and establish brand image, and in turn, build strong brand equity. As the recommendation, we suggest to study the effectiveness of CBBE strategy implementation in courier service industry for further research.

\section{REFERENCES}

[1] Barney, J.B., Strategic Management Journal, "Firm resources and sustained competitive advantage”, U.S.: Journal of Management, 1991, pp. 99-120.

[2] Bergen and Peteraf, Competitor identification and competitor analysis: A broad-based managerial approach, U.S.: Managerial and Decision Economics, 2002, pp. 157-169.

[3] Bluemelhuber, et al., Associative networks: A New Approach to Market Segmentation, Netherland: International Journal of Market Research, 2011, Vol. 53 Issue 2, pp. 187-207.

[4] Hoyer and Brown, Effects of Brand Awareness on Choice for a Common Repeat Purchase Product, U.S.: Journal of Consumer Research, 1990, pp. 141-148.

[5] Karou, Ishikawa, Guide to Quality Control, Tokyo: JUSE, 1968, pp. 1226.

[6] Keller, K. L., Strategic Brand Management Fourth Edition, Harlow U.K.: Pearson Education, 2012, pp. 29-385.

[7] Kioumarsi, et al., Customer satisfaction: The case of fresh meat-eating quality preferences and the USDA yield grade standard, US: American Canadian Conference, 2009, pp. 1912-1919.

[8] Kotler P. and Armstrong, Principles of Marketing, Harlow, U.K.: Pearson, 2017, pp. 1-736.

[9] Kotler, P., \& Keller, K. L., Marketing Management Fifteen Edition, Harlow, U.K.: Pearson Education Limited, 2015, pp. 2-324.

[10] MacDonald, Sharp, and Byron, Brand Awareness Effects on Consumer Decision Making for a Common, Repeat Purchase Product: A Replication, U.S.: Journal of Business Research, 2000, pp. 5-15.

[11] Malhotra, Basic Marketing Research: Integration of Social Media, US: Pearson, 2011, pp. 63-408.

[12] Rothaermel, Strategic Management (3e), New York US: McGraw-Hill Education, 2016, pp. 21-328.

[13] Villarejo and Shancez, The impact of marketing communication and price promotion on brand equity, Spain: Journal of Brand Management, 2005, pp. 431-444.

[14] https://databoks.katadata.co.id/datapublish/2019/06/12/biaya-logistikindonesia-tertinggi-di-asia.

[15] https://www.statista.com/outlook/243/120/ecommerce/indonesia.

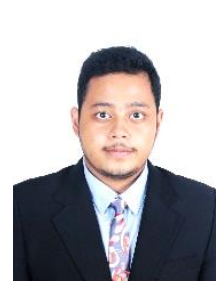

Fahmi Aulia Rahman is an MBA candidate from Bandung Institute of Technology with Marketing Management, Business Strategy, Communication, and Entrepreneurship concentration. He also active in three different local startups, which are automotive, food \& beverage, and oil, gas, \& mining business.

He received his bachelor degree from Geophysical Engineering, Sepuluh Nopember Institute of Technology Surabaya, continuing his master degree of MBA in Bandung Institute of Technology. His master thesis is creating CBBE strategy for national railway courier company product called "Rail Express", PT. Kereta Api Indonesia (Persero), to develop brand awareness and brand image in terms of developing market penetration.

In addition to his academic background, Fahmi also has experiences as founder and chief marketing and business development in "Garasi Asik" automotive startup, "Suguhan Nusantara" food \& beverage startup, and "PT. Abimantrana Lintas Nusantara" oil, gas, \& mining startup. Fahmi also has experience in working as Freight marketing research intern for PT. KAI (Persero). On his Geophysical and Geological backgrounds, Fahmi also has working experience as supervisor and intern in three different companies, such as PT. Satui Terminal Umum Coal Mining, Energi Mega Persada, Tbk, and Petronas Carigali Indonesia Operation.

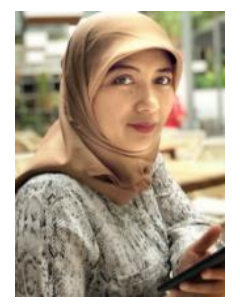

Nita Garnida is a Lecturer at the School of Business and Management, Institut Teknologi Bandung (SBM ITB). She received her bachelor degree from Chemistry Department, Bandung Institute of Technology and her master degree in Marketing Management from Mulawarman University. She continued her study and received her doctoral degree in Science of Management from School of Business and Management, Bandung Institute of Technology. In addition to her academics' background, Nita is also a practitioner. She has twelve years of experiences as a marketing manager in service company that serve oil and gas industry and four years of experiences as senior manager in mining operations. 